\title{
HIV/AIDS epidemic in the State of Amazonas: characteristics and trends from 2001 to 2012
}

\author{
Romina do Socorro Marques de Oliveira ${ }^{[1]}$, Adele Schwartz Benzaken ${ }^{[2]}$, \\ Valeria Saraceni ${ }^{[1],[3]}$ and Meritxell Sabidóó ${ }^{[1],[4]}$
}

[1]. Fundação de Medicina Tropical Doutor Heitor Vieira Dourado, Manaus, AM. [2]. Departamento de DST/Aids e Hepatites Virais, Secretaria de Vigilância em Saúde, Ministério da Saúde, Brasília, DF. [3]. Secretaria Municipal de Saúde do Rio de Janeiro, Prefeitura Municipal do Rio de Janeiro, Rio de Janeiro, RJ. [4]. Laboratori de Medicina Translacional i Ciències de la Decisió, Departamento de Ciências Médiques, Universitat de Girona, Girona, Catalunya.

\begin{abstract}
A scoping review was conducted to describe the epidemiological characteristics of the human immunodeficiency virus/acquired immunodeficiency syndrome (HIV/AIDS) epidemic in the State of Amazonas, Brazil, from 2001 to 2012, and temporary patterns were estimated from surveillance data. The results suggest that in its third decade, the Amazon HIV/AIDS epidemic is far from being stabilized and displays rising AIDS incidence and mortality rates and late diagnoses. The data suggest that AIDS cases are hitting mostly young adults and have recently shifted toward men, both homosexual and heterosexual. AIDS cases among the indigenous people have remained stable and low. However, the epidemic has disseminated to the interior of the state, which adds difficulties to its control, given the geographical isolation, logistical barriers, and culturally and ethnically diverse population. Antiretroviral (ARV) therapy has been decentralized, but peripheral ARV services are still insufficient and too distant from people who need them. Recently, the expansion of point-of-care (POC) rapid HIV testing has been contributing to overcoming logistical barriers. Other new POC devices, such as the PIMA CD4 analyzer, will bring the laboratory to the patient. AIDS uniquely coexists with other tropical infections, sharing their epidemiological profiles. The increased demand for HIV/AIDS care services can only be satisfied through increased decentralization to peripheral health units, which can also naturally integrate care with other tropical infections and can promote a shift from vertical to integrated programming. Future challenges involve building surveillance data on HIV case notification and covering the spectrum of engagement in care, including adherence to treatment and follow-up loss.
\end{abstract}

Keywords: AIDS. Mortality. Epidemiology. Trends. Amazon. Brazil.

\section{INTRODUCTION}

At the end of 2010, an estimated 34 million people were living with the human immunodeficiency virus/acquired immunodeficiency syndrome (HIV/AIDS) globally, of whom 1.4 million were from Latin America ${ }^{1}$. Although globally the number of people newly infected with HIV continues to decline, 2.5 million people became infected in 2011, with 83,000 cases living in Latin America. Worldwide, almost half (47\%) of new infections are women, and 39\% are young people aged 15-24 years. The annual number of people dying from AIDS-related causes worldwide has been steadily decreasing since 2005 to 1.7 million AIDS-related deaths in $2011^{(1)}$.

Brazil is home to approximately one-third of the people living with HIV/AIDS in Latin America ${ }^{(2)}$, with 656,701 AIDS cases registered as of June $2012^{(2)}$. An estimated 38,776 new

Corresponding author: Dra. Adele Schwartz Benzaken. SAF Sul, Trecho 02, Edifício Premium, Bloco F, Torre I Térreo, 70070-600 Brasília, DF, Brasil. Phone 5561 3315-7737; Fax: 5561 3315-8850

e-mail: adelebenz@gmail.com

Received 19 June 2013

Accepted 22 May 2014
AIDS cases were reported in 2011, which represents an increase of $28.2 \%$ from $2001(30,237)^{(3)}$. The incidence of newly reported AIDS cases has steadily increased from 17.5 cases per 100,000 persons in 2001 to 20.0 in 2011, but this trend varies greatly by region.

In Brazil, the reported number of AIDS deaths has increased from 10,948 cases in 2001 to 12,044 cases in 2011, which represents a $10 \%$ increase. The AIDS mortality rate has been continually declining each year, with $12 \%$ fewer AIDS-related deaths in 2011 ( 5.6 per 100,000 persons) than the reported 6.3 per 100,000 persons in 2001 , but again, trends vary by region ${ }^{(3)}$.

Brazil is classified as having a concentrated HIV/AIDS epidemic mainly driven by sexual transmission. Whereas the adult HIV prevalence in Brazil was $0.4 \%$ in 2010, HIV infection rates were substantially higher in men who have sex with men (MSM) $(14.2 \%)^{(4)}$, sex workers (SW), and intravenous drug users (IDUs; $4.8 \%$ and $5.9 \%$, respectively ${ }^{(5)(6)}$. Men still make up the majority of AIDS cases, with 1.7 men infected for every woman in 2012. Among men, the proportion of AIDS cases due to heterosexual transmission started to rise in the 1990s, but MSM still account for $29.2 \%$ of all AIDS cases reported in $\mathrm{Brazil}^{(3)}$.

The age group most affected by the epidemic is the 25- to 49-year-olds. In all age groups, men are more affected by AIDS 
than women. However, there is a pronounced gender gap among young people aged 13-19 years, with more women with AIDS than men since $1998^{(3)}$.

\section{THE EARLY YEARS OF THE HIV/AIDS EPIDEMIC IN THE STATE OF AMAZONAS}

Located in Northern Brazil, the State of Amazonas has $3,483,985$ inhabitants, $5.3 \%$ of whom are members of the indigenous population ${ }^{(7)}$. The state is characterized by geographic isolation and the lack of uniform access to health care services.

The first AIDS case in the State of Amazonas was in 1986. From that date to 1996, up to 350 AIDS cases and 46 AIDSrelated deaths were reported in 16 municipalities. AIDS case reporting from the early years of the Amazonas' epidemic displayed a concentration of the disease among men and a steep shift toward women, with 2 women infected for every 5 men infected. Almost three-quarters (74.6\%) of AIDS cases were 20-39 year olds. The main transmission route was sexual, with homosexual transmission accounting for half of the cases ${ }^{(8)}$.

To better understand the recent scenario of the HIV/AIDS epidemic in the State of Amazonas, we conducted a scoping review of articles searched in Medline, Web of Science, or Scientific Electronic Library Online (SciELO). Searches were performed in May 2013. Our aim was not to be exhaustive but to provide a description of HIV/AIDS cases, its patterns, and mortality in the State of Amazonas. We developed a specific search strategy that combined medical subject heading terms with keywords related to epidemiology and AIDS or HIV and Amazon or Amazonas or Brazil in either the title or the abstract. Studies in adult populations conducted in the State of Amazonas of any design published in English, Portuguese, or Spanish during the study period were included. We excluded case reports. Ninety-five articles were identified, and $87(91.6 \%)$ articles were excluded: 33 articles were not relevant to this review, 5 were pediatric studies, 8 were case reports, and 41 were not conducted in the State of Amazonas and/or were not about HIV/AIDS epidemiology.

We also analyzed data and temporal trends from AIDS cases reported to the Amazon surveillance system from 2001 to 2012. Data were extracted from two electronic surveillance subsystems facilitated by the local Division of the National Program on HIV/ AIDS and Sexually Transmitted Infections: 1) the Notifiable Disorders Information System [Sistema de Informação de Agravos de Notificação (SINAN)], which includes AIDS cases reported together with other epidemiological variables to better characterize the dynamics of the epidemic, and 2) the Mortality Information System [Sistema de Informaçoes sobre Mortalidade (SIM)], which registers data from the declaration of death document for every case of death, along with information on the death-related cause and date and the municipality where the death occurred. New AIDS cases were reported according to the national definition ${ }^{(9)}$, which was revised in 2003 to include a CD4 cell count less than 350 cells $/ \mathrm{mm}^{3}$. Men who have sex with men includes both homosexual and bisexual men that have sexual intercourse with other men. The data were analyzed with Stata version 11 (Stata Corp, College station, TX). We used the chi-square test, with a level of significance of $5 \%$, to check for homogeneity of proportions and to establish linear trends in the statistical analysis. Simple linear regression was used to evaluate the temporal pattern of new AIDS cases and deaths.

\section{THE LAST ELEVEN YEARS OF THE HIV/AIDS EPIDEMIC IN THE STATE OF AMAZONAS}

\section{New AIDS cases}

A significant rising trend in the absolute numbers of AIDS cases between 2001 and 2012 (Figure 1) was identified that indicated an increase from 300 cases in 2001 to 783 cases in 2012. The accumulated number of AIDS cases reported in 2012 was 6,255 .

Disease incidence also increased from an annual incidence rate of 10.34 new AIDS cases per 100,000 persons/year in 2001 to 21.80 cases in 2012. The AIDS incidence rate doubled in both sexes, remaining higher in men than in women over time. In men, the incidence rate increased from 12.69 per 100,000 persons in 2001 to 30.33 in 2011, whereas in women, the rate increased from 6.80 per 100,000 persons in 2001 to 13.17 in 2011 (Figure 2). Based on Notifiable Disorders Information System data, between $10 \%$ and $12 \%$ of patients are co-infected with tuberculosis at the moment of HIV diagnosis. At a reference hospital in Manaus, $46.8 \%$ of patients with AIDS had positive cultures for Mycobacterium tuberculosis, and 9.3\% had positive cultures for non-tuberculosis mycobacteria ${ }^{(10)}$. HIV/AIDS patients attended at the same reference hospital displayed a prevalence of coinfection with chronic hepatitis B carriage of $6.4 \%^{(11)}$, a hepatitis B past infection rate of $40.2 \%^{(11)}$, a hepatitis $\mathrm{C}$ infection rate of $4.42 \%{ }^{(12)}$, a leprosy infection rate of $0.76 \%{ }^{(13)}$, and an anal squamous intraepithelial lesion rate of $38.3 \%{ }^{(14)}$.

The baseline CD4 cell count recorded at the first patient visit at enrollment into care displayed a slightly increasing trend over time from 234 cells $/ \mathrm{mm}^{3}$ [interquartile range (IQR): 95-420] in 2005 to 257 cells $/ \mathrm{mm}^{3}$ (IQR: 103-439) in 2011. However, the CD4 count remained well below the threshold of 350 cells $/ \mathrm{mm}^{3}$, at which treatment was initiated until 2012 according to the World Health Organization (WHO) antiretroviral (ARV) therapy guidelines ${ }^{(15)}$.

\section{Transmission patterns}

Globally, $67.4 \%$ of AIDS cases were men. Over the years, the proportion of new AIDS cases in men increased from $65.4 \%$ in 2001 to $70 \%$ in 2012 . Trends in proportion fluctuated in both sexes from 2001 to 2007 and increased in men from 2008 to 2012. The increasing pattern in the number of AIDS cases by sex stayed the same over the years. From 2001 to 2012, the trend in the ratio of male-to-female patients fluctuated between 1.9 and 2.3, peaking at 2.5 in 2005 and returning to 2.3 in 2012.

Patients aged between 20 and 34 years accounted for the largest share (55\%) of new AIDS cases, followed by the 35to 49 -year age group (33\%) and the 15- to 19 -year age group (3\%). Overall, the age distribution of AIDS case reports among women was similar to the distribution among men, except for the youngest age group (13-19 years), in which women displayed a higher proportion of case reports $(4.9 \%$ of female cases vs. 2.6\% of male cases). From 2001 to 2012, the trends 


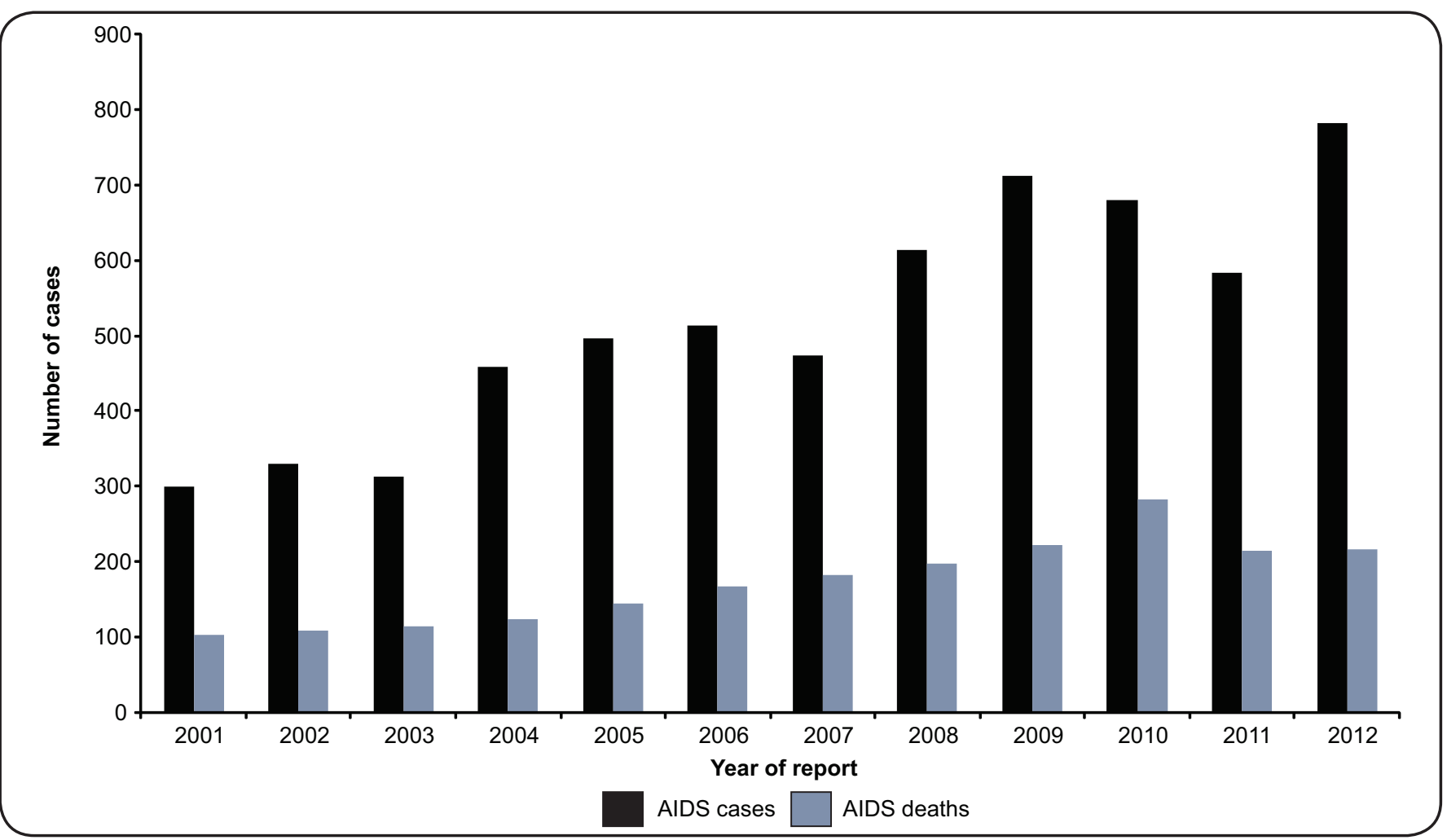

FIGURE 1 - Adult AIDS cases and AIDS related-deaths by year of report, State of Amazonas, 2001-2012. AIDS: acquired immunodeficiency syndrome.

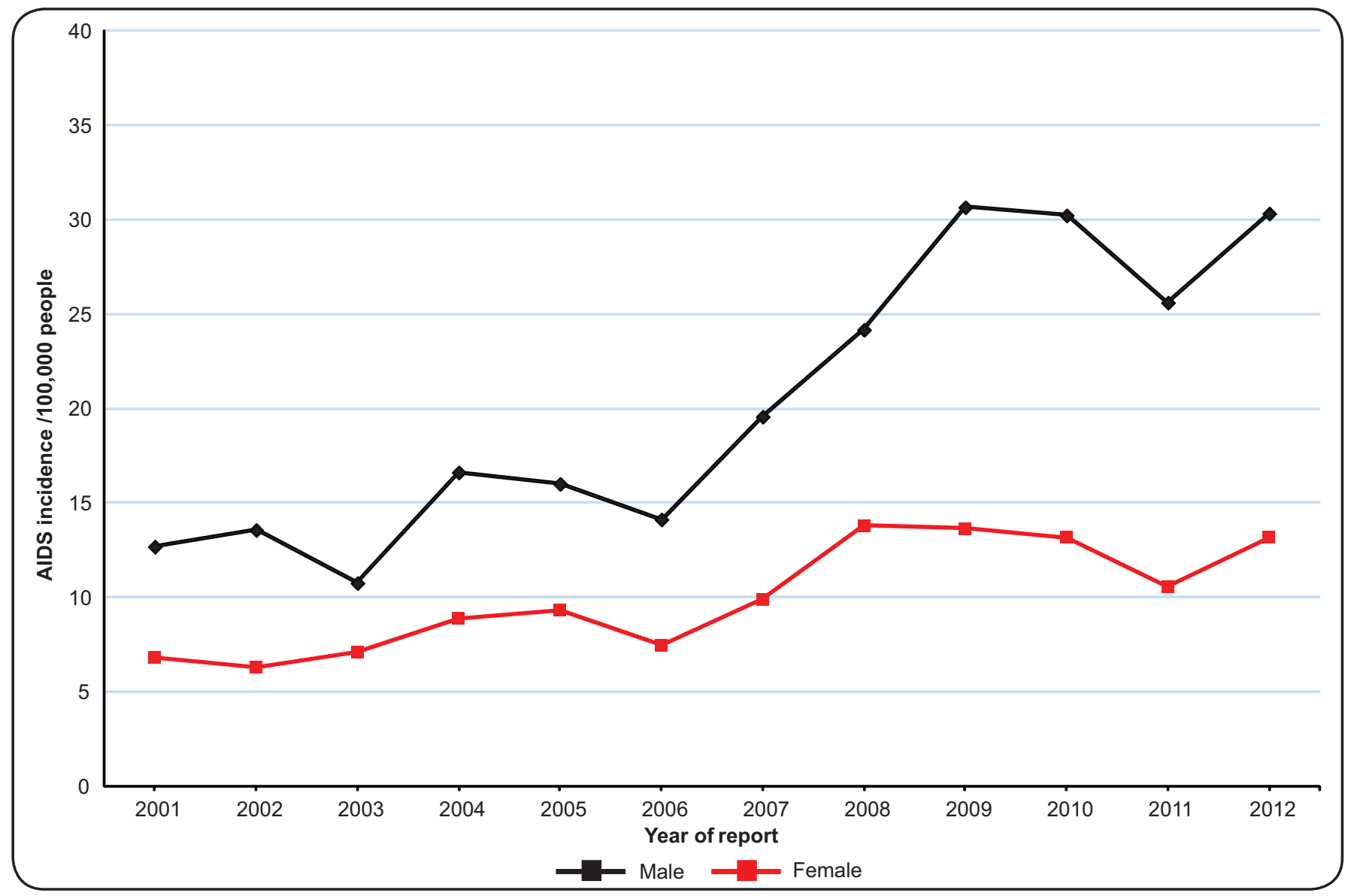

FIGURE 2 - AIDS incidence rates per 100,000 persons by sex and year of report, State of Amazonas, 2001-2012. AIDS: acquired immunodeficiency syndrome. 
in the proportions of adult AIDS cases remained stable in each age band (Figure 3).

Thirty-five municipalities had reported AIDS cases in 2001, 41 in 2004, 45 in 2006, 49 in 2008, and 49 in 2010. By 2012, $52(83.4 \%)$ out of 62 municipalities in the State of Amazonas had reported at least one case of AIDS (Figure 4). Considering that all municipalities reported equally, Manaus is the most affected city, with $86.7 \%$ of AIDS cases, followed by Parintins (2.3\%), Itacoatiara (1.5\%), and Tabatinga (0.1\%).

\section{Vulnerable populations}

From 2001 until 2012, MSM accounted for $27.8 \%$ of AIDS cases, IDUs for $2.2 \%$ ( $89 \%$ male and $11 \%$ female), and heterosexuals for $66.1 \%$ ( $51 \%$ male and $49 \%$ female). Among men, the number of AIDS cases displayed significant increasing trends in both MSM and heterosexual men (Figure 5). AIDS prevalence increased from 73 cases in 2001 to 83 cases in 2012 in MSM (p-value $=0.04$ ) and from 81 in 2001 to 113 in 2011 in heterosexual men ( $\mathrm{p}$-value $=0.03$ ). Studies in Manaus indicate HIV prevalence rates of $3 \%$ among sex workers screened in an outreach $\operatorname{clinic}^{(16)}$ and $0.7 \%$ among pregnant women attended at the reference hospital ${ }^{(17)}$. In the triple-border area of the Brazilian Amazon, vulnerable populations displayed an HIV prevalence of $1.4 \%$ in men, with no cases in women ${ }^{(18)}$.
Throughout the last 11 years, the number of annual AIDS cases has remained stable and low among the indigenous people from the State of Amazonas. This population group accounted for $0.4 \%$ of AIDS cases in 2001 and $0.8 \%$ in 2012 .

\section{AIDS mortality}

Throughout the years, the annual number of AIDSrelated deaths has displayed a steadily increasing trend, from 102 in 2001 to 216 in 2011, peaking in 2010 at 283 deaths (Figure 1). Mortality rates have followed the same pattern and have increased from 3.51 cases per 100,000 persons in 2001 to 6.01 cases per 100,000 persons in 2012. By 2012, 46 out of 62 municipalities (74.2\%) reported AIDS-related deaths (Figure 4). The City of Manaus reported $85.9 \%$ of AIDSrelated deaths, whereas cities and municipalities in the interior accounted for $14.1 \%$. In regards to the underlying causes of death, AIDS-related infections accounted for $77 \%$ of cases from 2001 to 2005. AIDS-related infections, including tuberculosis, increased up to the year 2005 and declined after that year. From 2006 to 2012, AIDS-related infections were replaced by an increase in non-specified causes related to AIDS as the leading cause of death. Based on autopsies performed in 129 AIDS patients at the reference hospital in Manaus from 1996 to 2003 , tuberculosis was also the leading cause of death $(28 \%)$, followed by bacterial pneumonia $(17 \%)^{(19)}$.

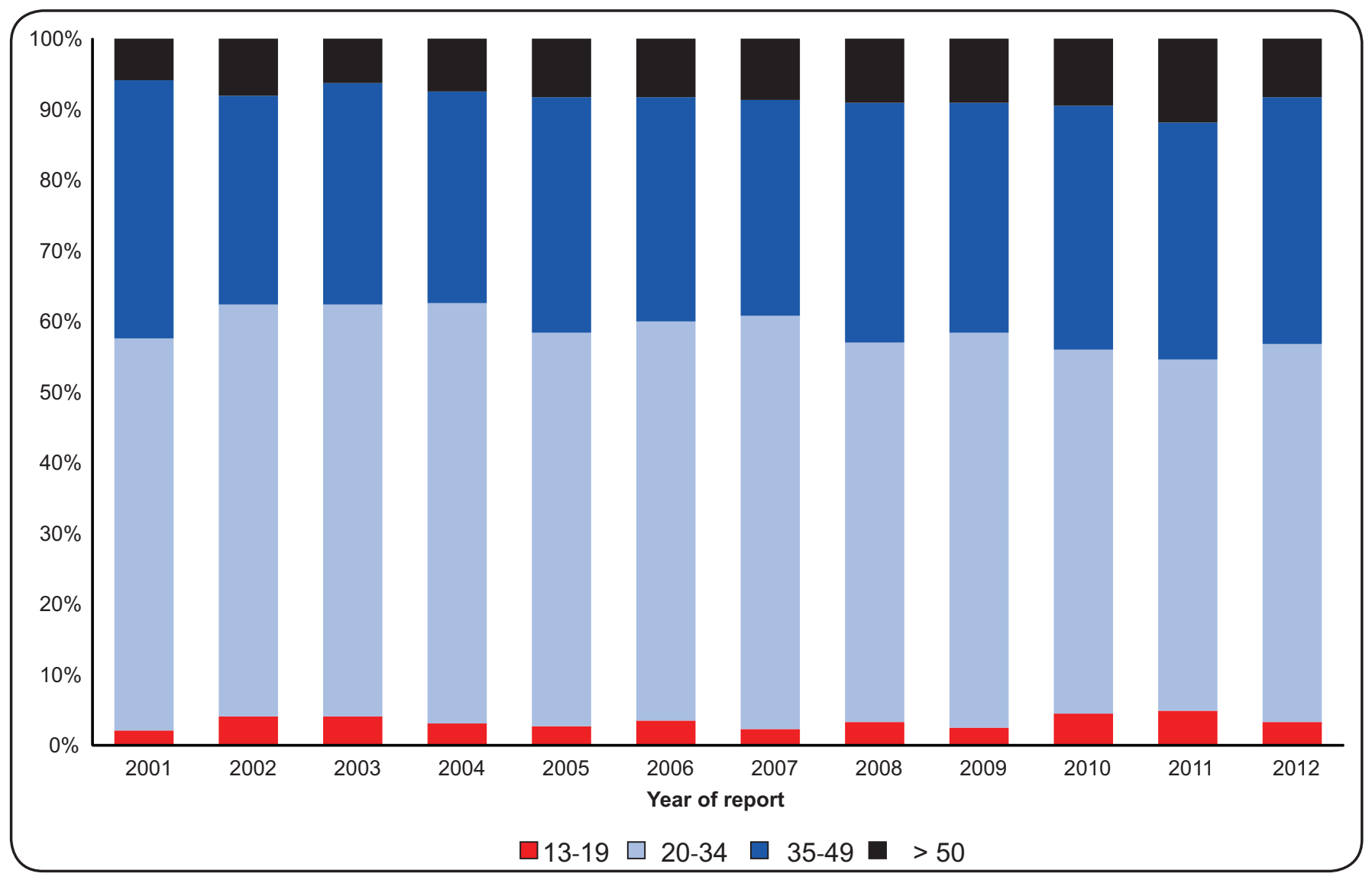

FIGURE 3 - Proportions of adult AIDS cases by age group at diagnosis and year of report, State of Amazonas, $2001-2012$. AIDS: acquired immunodeficiency syndrome. 


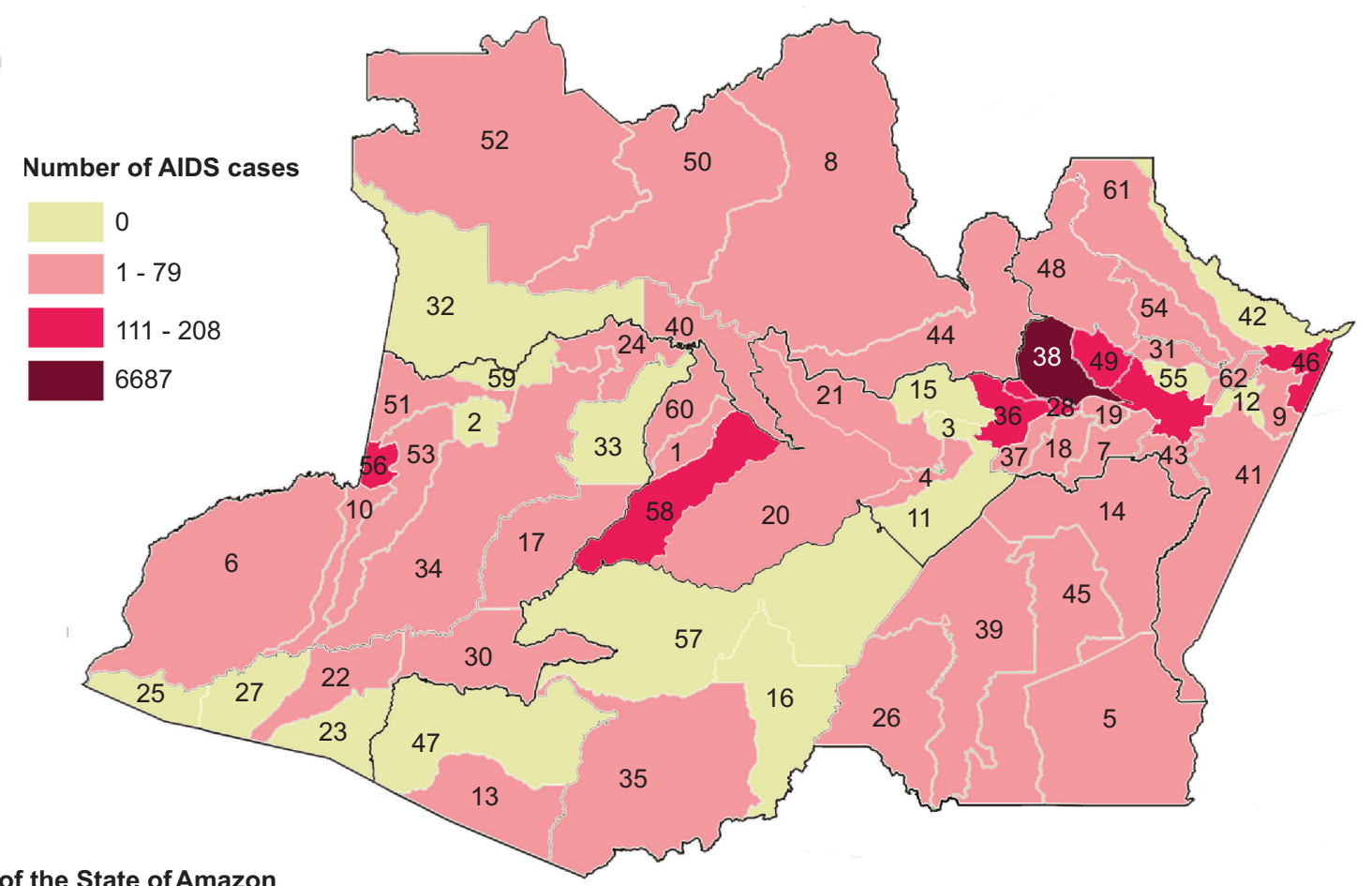

\section{Municipalities of the State of Amazon}

1. Alvarães
2. Amaturá
3. Anamã
4. Anori
5. Apuí
6. Atalaia do Norte
7. Autazes
8. Barcelos
9. Barreirinha
10. Benjamin Constant
11. Beruri
12. Boa Vista do Ramos

13. Boca do Acre

14. Borba
15. Caapiranga
16. Canutama
17. Carauari
18. Careiro
19. Careiro da Várzea
20. Coari
21. Codajás
22. Eirunepé
23. Envira
24. Fonte Boa
25. Guajará
26. Humaitá

27. Ipixuna

28. Iranduba

29. Itacoatiara

30. Itamarati

31. Itapiranga

32. Japurá

33. Juruá

34. Jutaí

35. Lábrea

36. Manacapuru

37. Manaquiri

38. Manaus

39. Manicoré
40. Maraã

41. Maués

42. Nhamundá

43. Nova Olinda do Norte

44. Novo Airão

45. Novo Aripuanã

46. Parintins

47. Pauini

48. Presidente Figueiredo

49. Rio Preto da Eva

50. Santa Isabel do Rio Negro

51. Santo Antônio do Ićá

52. São Gabriel da Cachoeira
53. São Paulo de Olivença 54. São Sebastião do Uatumã 55. Silves

56. Tabatinga

57. Tapauá

58. Tefé

59. Tonantins

60. Uarini

61. Urucará

62. Urucurituba

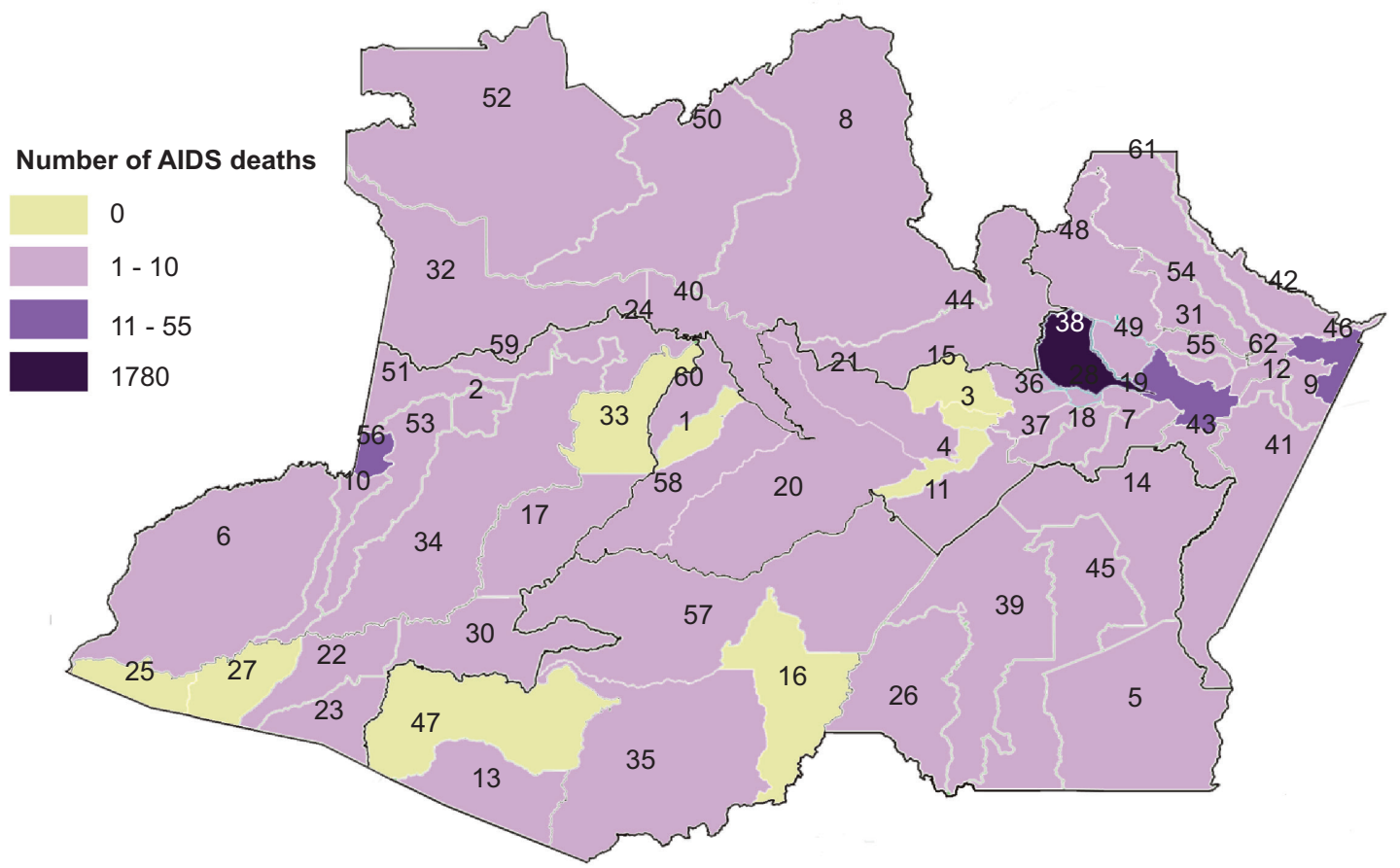

FIGURE 4 - AIDS cases and AIDS-related deaths by municipality, State of Amazonas, 2001-2012. AIDS: acquired immunodeficiency syndrome. 


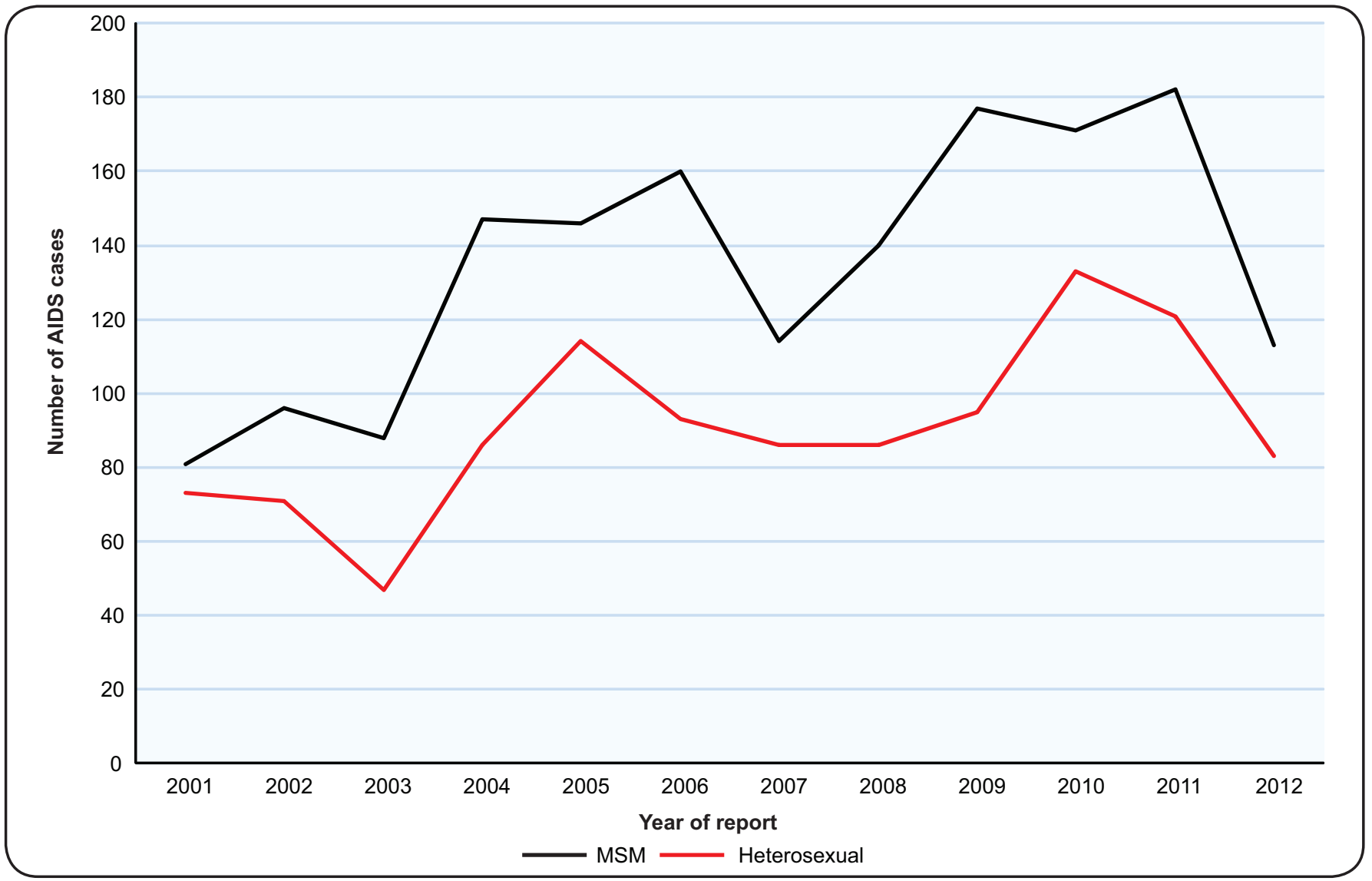

FIGURE 5 - Adult AIDS cases in men (n) by transmission group and year, State of Amazonas, 2001-2012. MSM: Men who have sex with men; AIDS: acquired immunodeficiency syndrome.

\section{CRITICAL EVALUATION OF CHANGES OBSERVED WITHIN THE CONTEXT OF PREVENTION AND CONTROL STRATEGIES}

The results suggest that the HIV/AIDS epidemic in the State of Amazonas is far from being stabilized, as indicated by the increase in the annual incidence of newly reported AIDS cases over the last 11 years. In fact, all regions in Brazil, except the south, have experienced increases in the AIDS incidence rate in the same period ${ }^{(3)}$. The states in the country that currently contribute the most to the HIV/AIDS epidemic are Rio Grande do Sul, Santa Catarina, Rio de Janeiro, and Amazonas, with incidence rates of $40.2,36.4,31.5$, and 29.4 per 100,000 persons in 2011, respectively ${ }^{(3)}$.

In the State of Amazonas, both the numbers of AIDS cases and AIDS deaths reported each year have more than doubled in the last 11 years, yielding a greater increase than the reported cases at the national level. In the State of Amazonas, the steady increase in mortality rate reported each year is worrisome given the contrast with the slight decline in death rates reported globally in the rest of the country over the same time period ${ }^{(3)}$. In Brazil, the mortality rate rose in all regions except the southeast, where it dropped, and in the central east region, where it remained stable ${ }^{(3)}$. In 2011, the State of Amazonas ranked third in mortality rate among the northern region states, following Roraima (7.7 per 100,000 persons) and Pará $(6.7 \text { per } 100,000 \text { persons })^{(3)}$. Compared with other states in the country, Amazonas was ranked sixth in 2011, with the three most affected states being Rio Grande do Sul (11.2 per 100,000 persons), Rio de Janeiro (8.9 per 100,000 persons), and Santa Catarina (7.6 per 100,000 persons).

Interestingly, the results suggest that the Amazonas HIV/ AIDS epidemic has moved toward men in recent years, with a greater disease incidence among men. Although nationally, Brazil presents the same trend ${ }^{(3)}$, the gender gap has been consistently larger in the State of Amazonas, with 2.5 AIDS cases in men for every women compared to 1.7 AIDS cases in Brazil. These results suggest that in the State of Amazonas, AIDS cases in men aged 13 years or older have grown both among MSM and heterosexual men. In the same time period in men 13 years or older, the proportion of cases attributed to heterosexual transmission has slightly risen, whereas the trend in MSM has remained stable. However, cases among MSM might be misclassified given that discrimination against MSM is widespread in the interior of the Amazonas, in particular among the indigenous people, affecting the disclosure of transmission groups. Nationwide, the HIV/AIDS epidemic among young MSM aged 15-24 years is growing. This group has progressively increased its contribution to AIDS cases among men, rising 
from $36.2 \%$ in 2001 to $48.3 \%$ in $2011^{(3)}$. In 10 Brazilian cities, almost half (47\%) of MSM lacked risk perception concerning HIV infection, $37.5 \%$ have never been tested for HIV, and $36.5 \%$ participated in unprotected receptive anal intercourse ${ }^{(20)}$.

These results suggest that in the State of Amazonas, the largest proportion of AIDS cases over time has been among people in their twenties and mid-thirties with no sex disparities. As in the rest of the country ${ }^{(3)}$, the differences in AIDS cases between men and women are more pronounced among the youngest age group (13-19 years). This observation might indicate that women are being infected with HIV at earlier ages than men. In Brazil, despite men initiating sexual intercourse earlier than women and having a greater number of partners, condom use during first sexual intercourse, in addition to other indicators regarding condom use, are consistently lower among women ${ }^{(21)}$.

In the State of Amazonas, AIDS cases among the indigenous people have remained stable and low over time. However, the Amazonas HIV/AIDS epidemic has disseminated from the City of Manaus to the interior of the state, which adds difficulties to its control given the geographical isolation, the logistical barriers, and the culturally and ethnically diverse population. Despite the HIV/AIDS infection rate among the indigenous people still being low at $0.11 \%^{(22)}$, a situational analysis on sexual health conducted in the Amazonian triple-border region revealed that main conditions that contribute to the spread of HIV were already in place ${ }^{(18)}$. In addition, the introduction of community-based screening for HIV and syphilis in remote indigenous people using rapid tests has brought testing to patients, increasing case detection ${ }^{(23)}$.

We have analyzed secondary data on AIDS cases reported to the Amazonas surveillance system, which is subject to some limitations. We lack information on the quality of the AIDS surveillance system in the State of Amazonas, i.e., on whether the system is representative of the whole state or is updated in a timely manner and its levels of completeness and accuracy ${ }^{(24)}$. We cannot rule out that the results are influenced by an increase or improvement in reporting or an increase in patients coming forward for treatment because of the increasing availability of ARV.

\section{FUTURE PERSPECTIVES}

In Brazil, in addition to free access to health care and ARV therapy, all people living with HIV/AIDS are also entitled to free access to CD4, viral load, and genotyping exams. However, these measure are not reversing the HIV/AIDS epidemic or its mortality in the State of Amazonas. At the end of 2010, Brazil was providing ARV therapy to at least $70 \%$ of people who needed it (based on the $2010 \mathrm{WHO}$ guidelines on initiating treatment at CD4 count $<350$ cells $\left./ \mathrm{mm}^{3}\right)^{(15)}$. This statistic represents an increase of $8 \%$ from December 2009, but Brazil still has not achieved universal access to ARV therapy, commonly understood as providing therapy to at least $80 \%$ of people who need $\mathrm{it}^{(2)}$.

More importantly, almost half (49\%) of HIV-infected individuals in Brazil do not present for HIV testing until late infection (CD4 count $<350$ cells $/ \mathrm{mm}^{3}$ ). Late presenters in Brazil tend to be men over age $40^{(25)}$. They are often ill, have a 50 -fold increase in their mortality risk ${ }^{(26)}$, and are less likely to respond to treatment when initiated ${ }^{(27)}$. The proportion of late presenters in Brazil has slightly decreased from 52\% in 2005 to $49 \%$ in 2011. However, in the State of Amazonas, the median CD4 cell count at diagnosis reported each year has been consistently lower than the national count $\left(235 \mathrm{vs} .283\right.$ cells $/ \mathrm{mm}^{3}$ in 2005 and 257 vs. 355 cells $/ \mathrm{mm}^{3}$ in 2011, respectively) $)^{(28)}$.

The nature of the Brazilian HIV/AIDS epidemic might change through strategies that encourage early identification of all HIV-infected individuals (test) and initiation of ARV therapy in these individuals (treat), which leads to dramatic reductions in the incidence of HIV infection ${ }^{(29)}$. However, the State of Amazonas is characterized by geographic isolation, a wide diversity of indigenous groups living in small municipalities or rural communities, extreme climate, fragile health infrastructure, lack of well-trained health and laboratory personnel, and lack of access to CD4 cell count and viral load testing, which are centralized in the reference hospital in Manaus. All of these factors are important barriers that might compromise the success of the implementation of test-and-treat strategies.

In recent times, technological advances in point-of-care (POC) rapid diagnosis and clinical monitoring of HIV/AIDS are contributing to overcoming these barriers and bringing the laboratory to the patient ${ }^{(30)}$. In the State of Amazonas, the expansion of rapid testing for HIV at voluntary counseling and testing (VCT) services allowed the implementation of same-day testing and treatment (STAT) strategies ${ }^{(31)}$. New POC devices, such as the PIMA CD4 analyzer (Alere PIMA CD4, Walthman, MA, USA), can rapidly and accurately identify CD4 counts with minimal operator training and infrastructural setup and with less cost than standard laboratory-based equipment, such as flow cytometers ${ }^{(30)}$.

In the State of the Amazonas, ARV therapy was initially limited to a reference hospital in Manaus. This centralized model posed barriers to access to treatment for patients from the interior of the state. In 2005, ARV was expanded to the interior of the Amazonas, and currently, 6 HIV/AIDS Specialized Health Care Services (Serviço de Atenção Especializada [SAE]) offer treatment in the Cities of Benjamim Constant, Borba, Coari, Parintins, Tefé, and Tabatinga. However, these services are still insufficient and too distant from people who need it. As an important advance, Brazil recently adopted treatment initiation immediately after the confirmation of the HIV diagnosis regardless the CD4 count ${ }^{(32)}$, which will further increase the number of people initiating treatment at an earlier stage every year.

Surveillance of the HIV/AIDS epidemic in Brazil has relied on mandatory AIDS case reporting. However, the Ministry of Health will now account for the cases of positive HIV diagnosis, expanding the notification and following the recommendations of the Pan American Health Organization (PAHO) ${ }^{(24)}$. This measure has already been adopted by States such as São Paulo, Pernambuco, Paraná, and the Federal District and is also employed in other Latin America countries, such as Paraguay, Uruguay, Argentina, and Chile. The reporting of HIV cases will provide a better characterization of populations with risk factors or recently infected individuals, help in allocating resources 
for prevention and treatment, and help in planning and evaluating intervention efficacy. Future challenges involve the necessity of building surveillance data to cover the spectrum of engagement in care ${ }^{(33)}$, including late HIV diagnosis [already gathered in the System for Control of Laboratory Exams (SISCEL) ${ }^{(34)}$, suboptimal linkage to and retention in HIV/AIDS care, insufficient use of antiretroviral therapy, and suboptimal adherence to therapy. Longitudinal HIV/AIDS information systems using electronic systems installed in services where HIV/AIDS patients are treated constitute a fundamental tool for generating information on the spectrum of engagement in care, for evaluating the quality of testing and treatment services, and for generating international indicators ${ }^{(35)}$.

A peculiarity of the HIV/AIDS epidemic in the State of Amazonas that might deserve future study is the coinfection with other tropical infections, such as malaria. These infections coexist at a high burden, sharing their epidemiological profile with AIDS, which creates a unique context in Latin America. A better integration of programs could help in the control of both infections in a setting where unusual co-morbidities associated with AIDS prevail.

\section{CONCLUSIONS}

These results suggest that, in its third decade, the Amazonas HIV/AIDS epidemic is far from being stabilized, as shown by the increases in both AIDS incidence and mortality. These data suggest that AIDS cases have recently shifted toward men, both homosexual and heterosexual, and are hitting mostly young adults. The State of Amazonas has experienced a process of interiorization that implies further difficulties in the prevention and control of the epidemic, given the logistical barriers, geographic isolation, and need for culturally adapted strategies. However, most cases are concentrated in Manaus, and although in the city, where operational barriers are greatly diminished and a reference hospital for specialized AIDS treatment and care exists, mortality rates are high, suggesting other contributing clinical factors, such as late diagnosis and low adherence to treatment. We also cannot rule out underreporting of deaths attributed to AIDS in a context where a substantial amount of infected subjects are unaware of their HIV status.

Late diagnosis is a major problem, and remote testing devices, such as rapid testing for HIV, which are already introduced in the national guidelines and used in VCT services across the state, can have a major role in the recently observed slight improvement of early diagnoses. Other POC technologies, such as CD4 count and viral load count, if proven accurate, will bring the laboratory to the patient.

More information is needed on the spectrum of treatment and care to better trace important outcomes, such as adherence to treatment and follow-up loss. In that context, the cohort data gathered through electronic longitudinal systems can better help to obtain relevant clinical and epidemiological indicators in a standardized and timely manner.

In the long-term, the increased demand for HIV/AIDS care services can only be satisfied through increased decentralization to peripheral health units in the interior of the Amazon, with the role of each type of unit being appropriately calibrated to the human and material resources available to it but fulfilling a minimum set of laboratory requirements, such as rapid CD4 cell count and viral load testing. HIV/AIDS care services can also be naturally integrated with the care of other tropical infections, such as malaria, and thus should promote a shift from vertical to integrated programming.

\section{ACKNOWLEDGMENTS}

We would like to thank Silvana de Lima e Silva from the Amazonas Division of the National Program on AIDS, Sexually Transmitted Infections, and Viral Hepatitis and Anderson Alvarenga Pereira from the National Program on AIDS, Sexually Transmitted Infections, and Viral Hepatitis, Epidemiological Surveillance and Vital Statistics Coordination, Brazilian Ministry of Health, for their support in providing key data for the study.

\section{CONFLICT OF INTEREST}

The authors declare that there is no conflict of interest.

\section{FINANCIAL SUPPORT}

This study was supported by the Programa Estratégico de Ciência, Tecnologia \& Inovação nas Fundações Estaduais de Saúde (PECTI/AM SAÚDE), Government of the State of Amazonas, Brazil. Dr. Sabidó received a fellowship as a senior visiting researcher at the Fundação de Medicina Tropical Dr. Heitor Vieira Dourado was funded by PECTI/AM SAÚDE.

\section{REFERENCES}

1. Joint United Nations Programme on HIV/AIDS (UNAIDS). Global report: UNAIDS report on the global AIDS epidemic 2012 (Internet). Geneva: UNAIDS; 2012. 212 p. Report No.: UNAIDS/JC2417E. (cited 2013 May 20). Available at: http://www.unaids.org/en/media/unaids/ contentassets/documents/epidemiology/2012/gr2012/20121120_ UNAIDS_Global_Report_2012_with_annexes_en.pdf

2. World Health Organization (WHO), UNICEF, Joint United Nations Programme on HIV/AIDS (UNAIDS). Global HIV/AIDS response: epidemic update and health sector progress towards universal access: progress report 2011 (Internet). Geneva: WHO; 2011. 233 p. (cited 2013 May 18). Available at: http://www.who.int/hiv/pub/ progress_report2011/en/

3. Secretaria de Vigilância em Saúde. Departamento de DST, Aids e Hepatitis Virais. Boletim Epidemiológico aids e DST 2012 (Internet). Brasília: Ministerio da Saúde do Brasil, 2012. 28 p. (cited 2013 May 05). Available at: http://www.aids.gov.br/publicacao/2011/boletim epidemiologico_2012

4. Kerr LR, Mota RS, Kendall C, Pinho AA, Mello MB, Guimaraes MD, et al. HIV among MSM in a large middle-income country. Aids 2012; 27:427-435.

5. Szwarcwald CL, Souza Junior PR, Damacena GN, Junior AB, Kendall C. Analysis of data collected by RDS among sex workers in 10 Brazilian cities, 2009: estimation of the prevalence of HIV, 
variance, and design effect. J Acquir Immune Defic Syndr 2011; 57 (suppl III):129-135.

6. Bastos FI, Malta M, Albuquerque E, Hacker M, Bertoni N, Pinho A, et al. Taxas de infecção de HIV e sífilis e inventario de conhecimento, atitudes e práticas de risco relacionadas às infecçoões sexualmente transmissíveis entre usuários de drogas em 10 municípios brasileiros. (slides) (Internet). Brasília (DF): FIOCRUZ; c2010. 30 slides: color, 2 × 2 in. (cited 2013 June 18). Available at http://sistemas.aids.gov.br/prevencao2010/sites/default/ files/page/2010/18.06.2010/MR_\%20ElisabethMaciel.pdf/

7. Instituto Brasileiro de Geografia e Estadística (IBGE). Sinopse do Censo Demográfico 2010. Tabela 1.4 - População nos Censos Demográficos, segundo as Grandes Regiões e as Unidades da Federação - 1872/2010. (Internet). (cited 2013 May 15). Available at: http://www.ibge.gov.br/home/estatistica/populacao/censo2010/ tabelas_pdf/Brasil_tab_1_4.pdf/

8. Benzaken A, Sardinha JC, Casado R. Aids no Amazonas: retrospectiva histórica e situação atual. In: Fundação Oswaldo Cruz, editor. Espaço Doença. Um olhar sobre o Amazonas. Rio de Janeiro (BR): FIOCRUZ; 1998. p. 101-105.

9. Secretaria de Vigilância em Saúde. Departamento de DST, Aids e Hepatitis Virais. Critérios de definição de casos de aids em adultos e crianças. Brasília: Ministerio da Saúde do Brasil; 2004. (Cited 2013 May 21). Available at: http://www.aids.gov.br/sites/default/files/ criterios_aids_2004.pdf/

10. Oliveira RSM, Tavares AM. Espectro Clínico-epidemiológico da infecção por micobactérias tuberculosas/não-tuberculosas e HIV/ AIDS da demanda de internação em hospital de referência em Manaus, Amazonas. (Master's thesis). (Manaus (BR)): Universidade do Estado do Amazonas - Fundação de Medicina Tropical do Amazonas; 2006. 63 p.

11. Braga WS, Costa Castilho M, Santos IC, Moura MA, Segurado AC. Low prevalence of hepatitis B virus, hepatitis D virus and hepatitis $C$ virus among patients with human immunodeficiency virus or acquired immunodeficiency syndrome in the Brazilian Amazonbasin. Rev Soc Bras Med Trop 2006; 39:519-522.

12. Victoria MB, Victoria FS, Torres KL, Kashima S, Covas DT, Malheiro A. Epidemiology of HIV/HCV coinfection in patients cared for at the Tropical Medicine Foundation of Amazonas. Braz J Infect Dis 2010; 14:135-140.

13. Talhari C, Mira MT, Massone C, Braga A, Chrusciak-Talhari A, Santos M, et al. Leprosy and HIV coinfection: a clinical, pathological, immunological, and therapeutic study of a cohort from a Brazilian referral center for infectious diseases. J Infect Dis 2010; 202:345-354.

14. Silva IT, Araújo JR, Andrade RV, Cabral CR, Gimenez FS, Guimarães AG, et al. Anal cancer precursor lesions in HIV-positive and HIV-negative patients seen at a tertiary health institution in Brazil. J Infect Dis 2010; 202:345-354.

15. World Health Organization (WHO). Rapid Advice: Antiretroviral therapy for HIV initiation in adults and adolescents - November 2009. (Internet). Geneva: WHO; 2009. 28 p. (cited 2013 May 18); 12:99. Available at: http://www.who.int/hiv/pub/arv/rapid_advice_art.pdf/

16. Benzaken AS, Sabido M, Galban EG, Pedroza V, Vasquez F, Araujo A, et al. Field evaluation of the performance and testing costs of a rapid point-of-care test for syphilis in a red-light district of Manaus, Brazil. Sex Transm Infect 2008; 84:297-302.

17. Machado Filho AC, Sardinha JF, Ponte RL, Costa EP, Silva SS, Martinez-Espinosa FE. Prevalence of infection for HIV, HTLV, HBV and of syphilis and chlamydia in pregnant women in a tertiary health unit in the western Brazilian Amazon region. Rev Bras Ginecol Obstet 2010; 32:176-183.

18. Benzaken A, Sabido M, Galban E, Rodrigues Dutra DL, Leturiondo AL, Mayaud P. HIV and sexually transmitted infections at the borderlands: situational analysis of sexual health in the Brazilian Amazon. Sex Transm Infect 2012; 88:294-300.

19. Souza SL, Feitoza PV, Araujo JR, Andrade RV, Ferreira LC. Causes of death among patients with acquired immunodeficiency syndrome autopsied at the Tropical Medicine Foundation of Amazonas. Rev Soc Bras Med Trop 2008; 41:247-251.

20. Rocha GM, Kerr LR, Brito AM, Dourado I, Guimaraes MD. Unprotected Receptive Anal Intercourse Among Men Who have Sex with Men in Brazil. AIDS Behav 2013; 17:1288-1295.

21. Secretaria de Vigilância em Saúde. Departamento de DST, Aids e Hepatitis Virais. Pesquisa de conhecimentos, atitudes e práticas na população brasileira de 15 a 64 anos 2008 (PCAP 2008). Brasília: Ministério da Saúde; 2008. (cited 2013 May 21). Available at: http:// www.aids.gov.br/publicacao/pcap-2008/

22. Benzaken AS, Pinto VM, Carvalho $\mathrm{CH}$, Peeling RW. Increasing access to HIV and syphilis screening in remote areas using rapid tests. Sex Transm Infect 2011; 87:A2.

23. Mabey DC, Sollis KA, Kelly HA, Benzaken AS, Bitarakwate E, Changalucha J, et al. Point-of-care tests to strengthen health systems and save newborn lives: the case of syphilis. PLoS Med 2013; 9:e1001233.

24. Pan American Health Organization (PAHO). Vigilancia de la infeccion por el VIH basada en la notificación de casos. Recomendaciones para mejorar y fortalecer los sistemas de vigilancia del VIH. (Internet). Washington, D.C.: PAHO; 2012. 64 p. Prepared by Alonso Gonzalez M, Sabidó M, García Calleja T. (cited 2013 May 19) Available at: http://www.paho.org/hq/index. php?gid=19091\&option=com_docman\&task=doc_download/

25. Grangeiro A, Escuder MM, Pereira JC. Late entry into HIV care: lessons from Brazil, 2003 to 2006. BMC Infect Dis 2012; 12:99.

26. Grangeiro A, Escuder MM, Menezes PR, Alencar R, Ayres de Castilho E. Late entry into HIV care: estimated impact on AIDS mortality rates in Brazil, 2003-2006. PLoS One 2011; 6:e14585.

27. Girardi E, Sabin CA, Monforte AD. Late diagnosis of HIV infection: epidemiological features, consequences and strategies to encourage earlier testing. J Acquir Immune Defic Syndr 2007; 46 (suppl I):3-8.

28. Alvarenga Pereira A. Coordenação de Cuidado e Qualidade de Vida. Departamento de DST, Aids e Hepatites Virais/SVS/MS. Jornada Nacional da Rede de Laboratórios de CD4 (slides). Florianópolis (SC): Ministerio da Saúde do Brasil; c2012. 10 slides: color, 2 x 2 in.

29. Dieffenbach CW, Fauci AS. Universal voluntary testing and treatment for prevention of HIV transmission. JAMA 2009; 301:2380-2382.

30. Shott JP, Galiwango RM, Reynolds SJ. A Quality Management Approach to Implementing Point-of-Care Technologies for HIV Diagnosis and Monitoring in Sub-Saharan Africa. J Trop Med 2012:651927.

31. Secretaria de Vigilância em Saúde. Departamento de DST, Aids e Hepatitis Virais. Portaria n 34 de 38 de julho de 2005. Regulamenta o uso de testes rápidos para diagnóstico da infecçao pelo HIV em situaçoes especiais. Diário Oficial União (Internet). Brasília: Ministério da Saúde do Brasil; 2005. (cited 2013 May 21). Available at: http://www.aids.gov.br/sites/default/files/anexo_3_4_002.pdf/

32. Secretaria de Vigilância em Saúde. Departamento de DST, Aids e Hepatites Virais. Global AIDS Response. Progress Reporting. Narrative Reporting. (Internet). Brasília: Ministério da Saúde do Brasil; 2014. 76 p. (cited 2013 May 18) Available at: http://www. unaids.org/sites/default/files/country/documents//BRA_narrative_ report_2014.pdf

33. Gardner EM, McLees MP, Steiner JF, Del Rio C, Burman WJ. The spectrum of engagement in HIV care and its relevance to test-andtreat strategies for prevention of HIV infection. Clin Infect Dis 2011; 52:793-800.

34. Lima RM, Dantas MCS, Vilel W.SISCEL: a nationwide system for managing CD4 and viral load exams in the Brazilian network of public health laboratories. XIII International AIDS Conference. Durban: South Africa; 2000.

35. Samayoa B, Isern V, Serra L, Rivera BE, Nikiforov M, Arathoon E, et al. Preliminary results of a prospective cohort of HIV+ patients in Guatemala: the MANGUA project. Poster presented at: XVIII International AIDS Conference; July 18-23. Vienna, Austria; 2010. 